\title{
Comments on Caddo Settlement Pattern and Culture Identity
}

Fank Winchell

Southern Methodist University

Follow this and additional works at: https://scholarworks.sfasu.edu/ita

Part of the American Material Culture Commons, Archaeological Anthropology Commons, Environmental Studies Commons, Other American Studies Commons, Other Arts and Humanities Commons, Other History of Art, Architecture, and Archaeology Commons, and the United States History Commons

Tell us how this article helped you.

This Article is brought to you for free and open access by the Center for Regional Heritage Research at SFA ScholarWorks. It has been accepted for inclusion in Index of Texas Archaeology: Open Access Gray Literature from the Lone Star State by an authorized editor of SFA ScholarWorks. For more information, please contact cdsscholarworks@sfasu.edu. 
Comments on Caddo Settlement Pattern and Culture Identity

Creative Commons License

(c) () () (9)

This work is licensed under a Creative Commons Attribution-NonCommercial 4.0 International License 


\section{Comments on Caddo Settlement Pattern and culture Identity}

Frank Winchell, Southern Methodist University

This discussion will be based primarily upon Schambach's work and observations on Caddo habitation settlements in the Great Bend area of Southwestern Arkansas (Schambach 1982a:1-11; 1982b:132197). Schambach believes that the basic Caddo settlement pattern is that of a dispersed hamlet configuration clustered around a specific civic-ceremonial center (Schambach 1982a:7). This settlement configuration is based upon archaeological work in the Great Bend area which conforms to a stylized but highly accurate map (the Teran Map of 1691-1692) drawn from an inhabited historic Caddo village compound presumably near the Hatchel Mound site (41BW3) on the west bank of the Red River in Texas (Schambach 1982a:7; Wedel 1978:10).

In order to incorporate the total spatial arrangement of settlements in the Caddo culure area of the Trans-Mississippi South, which encompasses a broad geographic region ranging from lowland forests to mountains and prairies (Schambach 1982b), it may be profitable to expand Schambach's model to include a composite settlement system which involves civic-ceremonial centers and their related hamlet settlements, with more remote hamlet clusters which are not directly associated with civicceremonial centers. The latter type of settlement, referred to herein as hinterland hamlet clusters, would tend to be located outside the prime riverine environments such as the Great Bend area. These hinterland hamlet clusters would be situated along smaller, upper river drainages, or on the outer fringes of the Caddo culture area. Some of these hamlets may consist of single household units analogous to historic pioneer homesteads of the Anglo-American frontier. Examples of hinterland hamlets are numerous, and some of the best documented archaeological examples are situated on the western fringes of the Caddo culture area in Northeast Texas (Hyatt and Doehner 1975; Skinner and Conners 1979; Bruseth and Perttula 1981; Bruseth and Martin 1987; Raab 1982; McGregor and Bruseth 1987; Peter and McGregor 1988).

\section{The Dispersed Settlement Pattern}

The Teran Map shows a basic settlement configuration of approximately 25 contiguous "small farmsteads" (Schambach 1982a:7) divided by makeshift fences or possible hedge rows composed of bushes or trees. These particular homesteads consist of one to two thatched huts (presumed to be households) with one or more storage platforms which appear to be elevated open air structures with a thatched roof overhead. Each dewliing and associated out building are within the fenced area, creating an open yard between structures. 
Theis kind of village compound arrangement is also shown in two photographs of the Caddo "long Hats Camp" in Eastern Oklahoma taken between 1862 and 1872 (Schambach 1982a:7-8). These particular photos show several round or square thatched huts (either with grass or bark roofs) with associated storage structures.

It is quite uncanny to see very similar thatched huts and elevated storage structures in both the soule photos and the Teran Map. It is even more remarkable that the overall settlement pattern of the Caddo village compound has changed very little from 1692 to 1872 , a 180 year span of history marked by tremendous social and political change (Story 1978:46-59) which seriously affected the caddo culture (Schambach 1982a:7). Nonetheless, a good case can be made for the dispersed Caddo village compound settlement pattern during the historic period based on the Teran Map and Soule photos (Schambach 1982a:7-10).

Based on this data, it would not be too adventurous to extrapolate back into the past and speculate that the settlement pattern of the prehistoric Caddo was similar to the caddo of the historic period. This can be further supported by archaeological data which has been recovered from the earliest to latest Caddo occupations in the Great Bend region (Schambach 1982a:7) and a number of sites in the overall caddo culture area. What is clear is that there were no (or at best, very few - such as the George C. Davis Site; see Newell and Krieger 1949; Story 1972, 1981) nucleated village settlements at any of the mound centers in the caddo culture area either during the prehistoric or historic period (Schambach 1982a:7).

Therefore, the dispersed hamlet configuration, consisting of one to two habitation huts with one or more associated out-buildings, was the primary caddoan pattern of settlement. In the archaeological record, this kind of nonnucleated settlement pattern would by very ephemeral and in many cases could by easily written off as "minor camps" or "minor refuse areas" (Schambach $1982 \mathrm{a}: 8)$.

\section{The Question of Caddo Culture Identity in Conjunction with the Dispersed settlement Pattern}

Unlike archaeological data recovered from mounds or cemeteries, these primary Caddo occupation components (the dispersed hamlet compound) would lack a fundamental and characteristic caddoan culture element - elaborate burials associated with diagnostic caddo artifacts. Thus, the hallmarks of the caddo culture milieu would be profoundly absent from much of the archaeological record concerning the dispersed hamlet configuration. It is perhaps more disconcerting to realize that what is known about caddoan material culture is based primarily on burials and associated grave paraphernalia. This fact (the lack of diagnostic Caddoan artifacts recovered from the archaeological record) is further 
exacerbated when Caddo habitation sites (i.e., hamlets) are situated farther away from the civic-ceremonial center.

Upon excavating the isolated Caddo hamlet occupations, several latent misconceptions may be brought to light. One is that these settlements may be looked upon as minor, separate Caddo hamlets removed from the major civic-ceremonial center. This would probably be the logical explanation for hamlets situated more than several kilometers from the center of any mound site. Given the dispersed settlement pattern configuration, it is more probable that these isolated hamlets are actually part of the Caddo settlement "metroplex" related to a particular mound site in a given area.

In cases involving clusters of Caddo hamlets without a primary civic ceremonial center (such as hinterland settlements), the misconception of them being a minor settlement would be further compounded by the possiblility of them being ethnically nonCaddo, especially with groups of settlements on the periphery of the Caddo culture area.

In reference to these more remote caddo occupations, some archaeologists may become hard pressed to define an isolated hamlet occupation as truly "Caddoan" in the absence of characteristic burials and lack of any good sample of decorated Caddo ceramics, marine shells, characteristic pipes, etc. of course, this would not be a problem with small hamlet sites situated well within the Caddo culture area. However, small hamlets located some distance away from any known Caddo center (especially those in the peripheral areas) would become more problematic as to whether they were truly caddoan.

In the western reaches of the Caddo area, one could probably construct a model based on the inverse relationship of diminishing Caddo "ethnicity" as the distance between hamlets and the civic-ceremonial center increased. However, if the dispersed settlement pattern of the Caddo is invoked, including both the civic-ceremonial center/farmstead arrangement and the hinterland hamlet cluster, this model may fail to accurately reflect the true distribution of Caddo occupations.

One might argue that in addition to the fact that these hinterland hamlets lacked many of the Caddo cultural essentials such as "Caddo burials" and other diagnostics, other factors such as the lack of cultigens, or proof of sedentism, coupled with the situation that they were located in environmental zones different from the Caddo area, would reasonably support the contention that the occupiers of these hamlets were non-caddo. On the other hand, this assumption begs several questions concerning whether the Caddo peoples were (1) of one social order, (2) practiced the same economic strategy, and (3) lived exclusively in the woodland environments of the Trans-Mississippi South.

The question of whether the caddo were of one social order, such 
as the presence of paramount individuals in a chieftain society, is flawed. In reality, elites were probably always associated in close proximity with the civic-ceremonial center. outside the immediate confines of the civic-ceremonial center, the chances of demonstrating class or status differences (high status burials, household/settlement hierarchies, etc.) in the archaeological record may be next to impossible. It is quite conceivable that many of the Caddo settlements (including some centers) were of an egalitarian nature (without institutional elites) of a tradermiddlemen society, which was very different from a chieftainredistribution type of system.

Concerning the economic base, it is very probable that the caddo did not have a maize based economy until sometime after A.D. 1250 (Rose et al. 1984; Rose and Hoffman 1989). It can be further argued that some caddo peoples never did adopt fully to a sedentary horticultural system. Furthermore, there may be a disproportionate amount of maize at the civic-ceremonial centers, especially if the centers were used as foci of tribute and redistribution.

Environmentally, it is conceivable that the Caddo did not restrict themselves solely to a woodland niche, especially when the forest fringe areas were reduced to more xeric types of habitats during extended dry spells (Lynott 1979). On the western fringes of the Caddo area, there is evidence that bison and other types of non-woodland resources were being actively exploited, either being imported as products from other plains tribes, or hunted by particular caddo groups venturing out into the prairies. The sanders site in northcentral Texas is a prime example (Krieger 1946). In addition to bison, the use of shell tempered ceramics in these western areas by the latter part of the prehistoric Caddo sequence certainly points to some kind of interaction with contemporary Plains village tribes (Peter and McGregor 1988).

Thus, the pure caddo culture milieu of the southern cult/CivicCeremonial Center Complex breaks down into a more intricate amalgamation of different aspects of an active society, presumably sharing a common language, interacting not only among themselves and with tribes to the southeast, but with other groups from the Plains to the Rio Grande, incorporating nonCaddoan traits which in the archaeological record would reflect very different kinds of components with varying social, economic, and environmental characteristics. Looking at the Caddo in this way, a composite settlement pattern system involving a dispersed hamlet configuration clustered around a civic-ceremonial center, in addition to a hinterland hamlet settlement sub-system, may be a more heuristic way to depict the entire caddo culture milieu.

\section{Conclusion}

In the end, we are left with the humble abode of the caddo village compound settlement pattern which in all intents and 
purposes was the mainstay of the caddo culture and economy, whether it be near a civic-ceremonial center or in the caddo hinterlands. The caddo village compound represents a complex arrangement of varying culture components which requires the researcher to be ever cognizant of a number of different combinations which confounds the traditional Burial Complex Caddo cultural configuration.

In the domain of CRM archaeology, these kinds of sites are increasingly becoming more visible, requiring a need for more systematic examination. As these sites become more a part of the Caddo archaeological data base, a multitude of new issues must be addressed. For example, existing ceramic classificatory schemes must be tailored to the more mundane and utilitarian nature of these hamlet pottery assemblages. Furthermore, a model based on a single economic base for the Caddo (such as a maize based mode of production) will simply not work. Finally, more research needs to be done in terms of how Caddo people adapted to the multitude of different environments which existed within the Caddo culture area, especially those which interfaced with the prairies in the west.

\section{References cited}

Bruseth, James E. and Timothy K. Perttula

1981 Prehistoric Settlement Patterns at Lake Fork Reservoir. Southern Methodist University and Texas Antiquities Committee. Texas Antiquities Permit series, Report No. 2. Archaeology Research Program Press, SMU, Dallas.

Bruseth, James E. and William A. Martin (editors)

1987 The Bird Point Island and Adams Ranch Sites: Methodological and Theoretical Contributions to North Central Texas Archaeology. Richland Creek Technical Series, Volume II. Archaeology Research Program, Southern Methodist University, Dallas.

Hyatt, Robert D. and Karen Doehner

1975 Archaeological Research at Cooper Lake, Northeast Texas, 1973. Southern Methodist University, Institute for the Study of Earth and Man, Dallas.

Krieger, Alex D.

1946 Culture Complexes and Chronology in Northern Texas with Extension of Puebloan Dating to the Mississippi Valley. University of Texas Publication No. 4640, Austin.

Lynott, Mark J.

1979 Prehistoric Bison Population of Northcentral Texas. Bulletin of the Texas Archeological Society 50:89-101. 
McGregor, Daniel E. and James E. Bruseth (editors)

1987 Hunter-Gatherer Adaptations Along the Prairie Margin: Site Excavations and synthesis of Prehistoric Archaeology. Richland creek Technical Series, Volume III. Archaeology Research Program, Southern Methodist University, Dallas.

Newell, H. Perry and Alex D. Krieger

1949 The George C. Davis Site, Cherokee County, Texas. Society for American Archaeology Memoirs No. 4.

Peter, Duane E. and Daniel E. McGregor (editors)

1988 Late Holocene Prehistory of the Mountain creek Drainage. Joe Pool Lake Archaeology Project, Volume 1. Archaeology Research Program, Southern Methodist University, Dallas.

Raab, L. Mark (editor)

1982 Settlement of the Prairie Margin: Archaeology of the Richland Creek Reservoir, Navarro and Freestone Counties, Texas 1980-1981: A Research Synopsis. Archaeology Research Program, Southern Methodist University, Dallas.

Rose, Jerome C. and Michael P. Hoffman

1989 Maize Dependency in the Trans-Mississippi South. MS on file at the Department of Anthropology, University of Arkansas, Fayetteville.

Rose, Jerome C., Barbara A. Burnett, Michael S. Nassaney, and Mark W. Blauer

1984 Paleopathology and the Origins of Maize Agriculture in the Lower Mississippi Valley and Caddoan Culture Areas. In Paleopathology at the Origins of Agriculture, edited by Mark N. Cohen and George J. Armelagos, pp. 393-425. Academic Press, New York.

Schambach, Frank F.

$1982 \mathrm{a}$ The Archeology of the Great Bend Region in Arkansas. In Contributions to the Archeology of the Great Bend Region, edited by Frank F. Schambach and Frank Rackerby, pp. 1-11. Arkansas Archeological Survey Research Series No. 22, Fayetteville.

1982b An Outline of Fourche Maline culture in southwest Arkansas. In Arkansas Archeology in Review, edited by Neal L. Trubowitz and Marvin D. Jeter, pp. 132-197. Arkansas Archeological Survey Research Series No. 15, Fayetteville. 
Skinner, S. Alan and Deborah T. Connors

1979 Archaeological Investigations at Lakeview Lake. Archaeology Research Program, Southern Methodist University, Dallas.

Story, Dee Ann

1972 A Preliminary Report of the 1968, 1969, and 1970 Excavations at the George C. Davis Site, Cherokee County, Texas. University of Texas at Austin. Submitted to the National Science Foundation.

1978 Some Comments on Anthropological Studies Concerning the Caddo. In Texas Archeology: Essays Honoring R. King Harris, edited by Kurt D. House, pp. 46-68. Institute for the study of Earth and Man, Reports of Investigations, No. 3, Southern Methodist University Press, Dallas.

1981 An Overview of the Archeology of East Texas. Plains Anthropologist 26:139-156.

Wedel, Mildred Mott

1978 La Harpe's 1719 Post on the Red River and nearby Caddo Settlements. Texas Memorial Museum Bulletin 30, Austin.

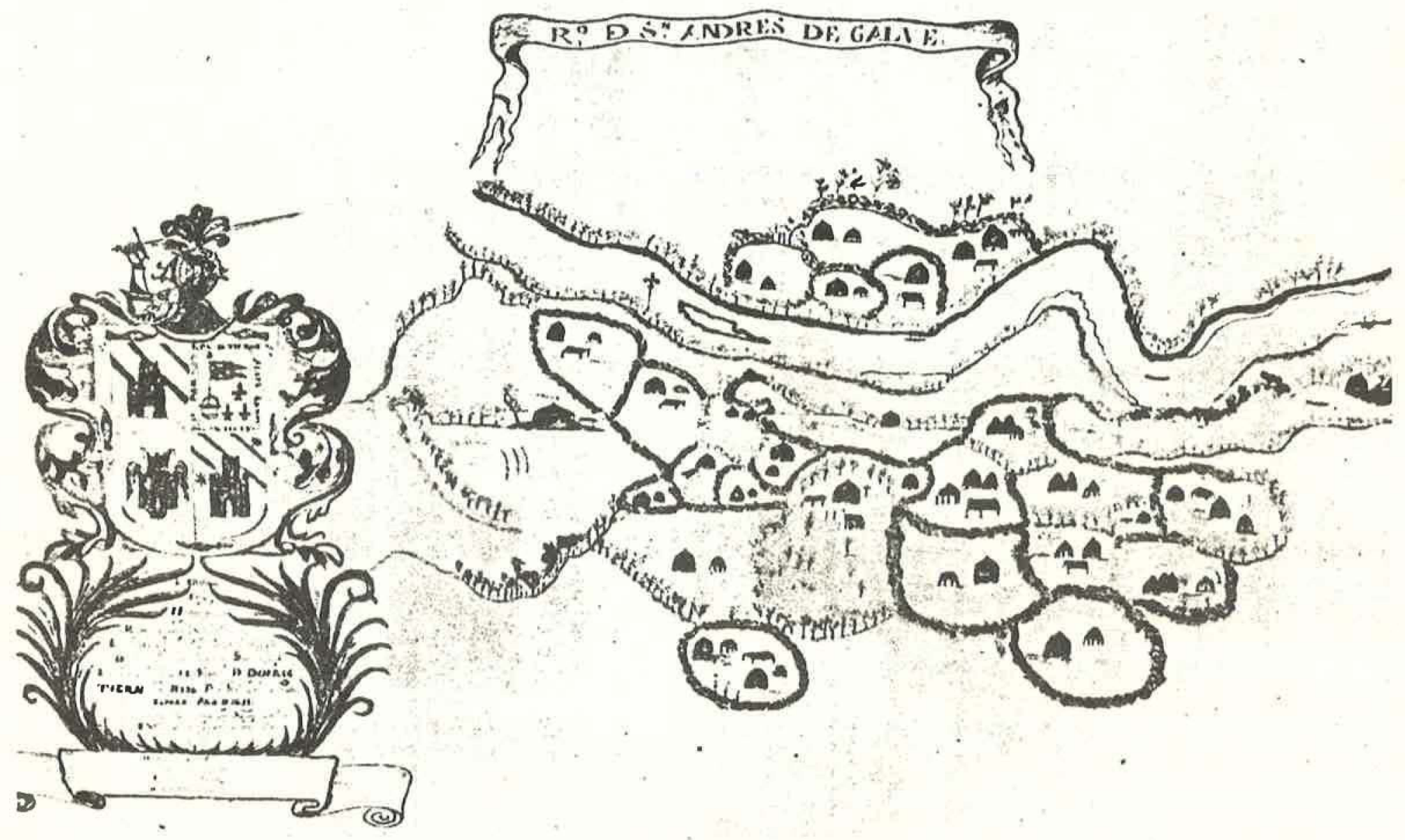

Taran map of 1691-1691 shows example of Caddo hamlet configuration. 